\title{
D-Serine as a Neuromodulator: Regional and Developmental Localizations in Rat Brain Glia Resemble NMDA Receptors
}

\author{
Michael J. Schell, ${ }^{1}$ Roscoe O. Brady Jr., ${ }^{1}$ Mark E. Molliver, ${ }^{1}$ and Solomon H. Snyder ${ }^{1,2,3}$ \\ Departments of ${ }^{1}$ Neuroscience, ${ }^{2}$ Pharmacology and Molecular Sciences, and ${ }^{3}$ Psychiatry, Johns Hopkins University \\ School of Medicine, Baltimore, Maryland 21205
}

\begin{abstract}
D-Serine is localized in mammalian brain to a discrete population of glial cells near NMDA receptors, suggesting that D-serine is an endogenous agonist of the receptor-associated glycine site. To explore this possibility, we have compared the immunohistochemical localizations of D-serine, glycine, and NMDA receptors in rat brain. In the telencephalon, D-serine is concentrated in protoplasmic astrocytes, which are abundant in neuropil in close vicinity to NMDA receptor $2 \mathrm{~A} / \mathrm{B}$ subunits. Ultrastructural examination of the $\mathrm{CA} 1$ region of hippocampus reveals $D$-serine in the cytosolic matrix of astrocytes that ensheath neurons and blood vessels, whereas NR2A/B is concentrated in dendritic spines. By contrast, glycine immunoreactivity in telencephalon is the lowest in brain. During postnatal week 2, D-serine levels in cerebellum are comparable to those in adult cerebral cortex but fall to undetectable levels by day 26 .
\end{abstract}

During week 2, we observe parallel ontogeny of D-serine in Bergmann glia and NR2A/B in Purkinje cells, suggesting a role for astrocytic D-serine in NMDA receptor-mediated synaptogenesis. D-Serine in the radial processes of Bergmann glia is also well positioned to regulate NMDA receptor-dependent granule cell migration. In the inner granule layer, D-serine is found transiently in protoplasmic astrocytes surrounding glomeruli, where it could regulate development of the mossy fiber/granule cell synapse. D-Serine seems to be the endogenous ligand of glycine sites in the telencephalon and developing cerebellum, whereas glycine predominates in the adult cerebellum, olfactory bulb, and hindbrain.

Key words: D-serine; glycine; NMDA receptor; glia; D-amino acid; cerebellum
Activation of NMDA receptor channels requires both glutamate and stimulation of a "glycine site" (Johnson and Ascher, 1987; Reynolds et al., 1987; Kemp and Leeson, 1993). Neurophysiological studies of expressed NMDA receptors indicate that with certain combinations of NR1 and NR2 subunits, D-serine is up to three times more potent than glycine at the glycine site (Matsui et al., 1995; Priestley et al., 1995). Although D-amino acids have long been known to exist in bacteria, worms, and insects (Corrigan, 1969), only very recently have high levels of D-serine been demonstrated in mammalian tissues, especially in the brain (Hashimoto et al., 1992a, 1993a,b; Nagata, 1992; Chouinard et al., 1993; Nagata et al., 1994).

We have mapped D-serine immunohistochemically in rat brain and observed a pattern that parallels the localization of D-serine binding sites associated with NMDA receptors in the forebrain (Schell et al., 1995). D-Serine is concentrated in gray matter regions enriched in NMDA receptors and is selectively localized to protoplasmic astrocytes. We have also demonstrated that agonists of non-NMDA receptors enhance the efflux of preloaded D-serine from cultures of cortical type 2 astrocytes. These data

Received Oct. 24, 1996; revised Dec. 16, 1996; accepted Dec. 19, 1996.

This work was supported by United States Public Health Service Grant MH 18501, a gift from the Theodore and Vada Stanley Foundation, Research Scientist award DA 00074 from the National Institute on Drug Abuse, and The Alan McAfee Baldwin Memorial Fund for Schizophrenia to S.H.S. M.E.M. was supported by Grant 5RO1DA04431 from the National Institute on Drug Abuse. We thank Mike Delannoy and Jiao Li for assistance with electron microscopy.

Correspondence should be addressed to Solomon H. Snyder, Department of Neuroscience, Johns Hopkins University School of Medicine, 725 N. Wolfe Street, Baltimore, MD 21205.

Dr. Schell's present address: Department of Pharmacology, Tennis Court Road, University of Cambridge, Cambridge CB2 1QJ, UK.

Copyright (C) 1997 Society for Neuroscience $\quad 0270-6474 / 97 / 171604-12 \$ 05.00 / 0$ suggest that D-serine is an endogenous ligand at the glycine site of many NMDA receptors and that glutamate releases D-serine from glial cells in the vicinity of NMDA receptors to synergize with synaptic glutamate (Cull-Candy, 1995; Schell et al., 1995).

To compare the candidacies of glycine and D-serine as endogenous ligands for NMDA receptors, we have studied their immunohistochemical localizations in serial sections of rat brain. We report a close similarity in the localizations of NMDA receptor 2A/B subtypes and D-serine, including a parallel transient ontogeny in the cerebellum, whereas the disposition of glycine differs substantially. We have also localized D-serine at the ultrastructural level, where it is concentrated in astrocytic foot processes and glial elements in neuropil.

\section{MATERIALS AND METHODS}

Antibodies. A polyclonal antibody to D-serine was raised in rabbits against a reduced glutaraldehyde conjugate of $\mathrm{D}$-serine and bovine serum albumin (BSA) and negatively purified against glutaraldehyde-treated BSA as described (Schell et al., 1995). In dot blot experiments, the antibody readily detects $0.01 \mathrm{nmol}$ of D-serine conjugated to brain protein and is 100 -fold less sensitive to L-serine. This antiserum was used at a dilution of 1:3000 in the presence of $200 \mu \mathrm{M} \mathrm{L}$-serine-glutaraldehyde liquid phase conjugate. In dot blots and in tissue sections, immunoreactivity is abolished by preincubation with $200 \mu \mathrm{M}$ of the D-serine conjugate. The antibody recognizing NMDA receptor $2 \mathrm{~A}$ and $2 \mathrm{~B}$ subunits (Chemicon, Temechula, CA) was generated against a C-terminal peptide of NR2A and has been characterized thoroughly (Petralia et al., 1994a). The polyclonal antibody to glycine was raised against a reduced glutaraldehyde conjugate of glycine and BSA and has at least a 100 -fold selectivity over $\beta$-alanine and a 1000 -fold selectivity over other amino acids tested. This antiserum was purchased commercially (Chemicon) and then negatively purified against glutaraldehyde-treated BSA as described for the D-serine antibody; it was used at a dilution of 1:3000 in the presence of the L-serine liquid-phase conjugate.

Immunohistochemistry. Sprague Dawley rats were obtained from Sasco 
(Wilmington, MA). Juvenile rats were littermates housed with their mother, whereas adult animals were males housed four to a cage at the Johns Hopkins Animal Care Facility. Animals were anesthetized with an overdose of sodium pentobarbitol and then [on postnatal days 7 (P7), 9, $11,13-19,21,50,60)$ perfused through the aorta with $37^{\circ} \mathrm{C}$ oxygenated Krebs-Henseleit buffer ( $118 \mathrm{mM} \mathrm{NaCl}, 4.7 \mathrm{mM} \mathrm{KCl}, 2 \mathrm{mM} \mathrm{CaCl}_{2}, 1.2 \mathrm{~mm}$ $\mathrm{MgSO}_{4}, 1.2 \mathrm{mM} \mathrm{KH} \mathrm{PO}_{4}, 25 \mathrm{~mm} \mathrm{NaHCO}$, and $1 \mathrm{~mm}$ glucose) for $\sim 45$ sec and then with $250-450 \mathrm{ml}$ of $37^{\circ} \mathrm{C} 5 \%$ glutaraldehyde (Electron Microscopy Sciences, Fort Washington, PA), $0.5 \%$ paraformaldehyde, $0.2 \% \mathrm{Na}_{2} \mathrm{~S}_{2} \mathrm{O}_{5}, 0.1 \mathrm{M}$ sodium phosphate, $\mathrm{pH}$ 7.4. After a $20 \mathrm{~min}$ delay, brains were removed, trimmed, and post-fixed for $2 \mathrm{hr}$ at room temperature. Brains were then placed in $4^{\circ} \mathrm{C}$ cryoprotection buffer $(20 \%$ glycerol, $1 \% \mathrm{NaCl}, 0.01 \%$ thimerosal, $50 \mathrm{~mm}$ sodium phosphate, $\mathrm{pH} 7.4$ ) for at least $2 \mathrm{~d}$ before they were frozen-sectioned $(20-40 \mu \mathrm{m})$ on a sliding microtome. Sections were reduced for $20 \mathrm{~min}$ in $0.5 \% \mathrm{NaBH}_{4}\left(\mathrm{Kosaka}_{\mathrm{N}} \mathrm{et}\right.$ al., 1986) and immunostained using the Vectastain Elite kit (Vector Labs, Burlingame, AC) as described (Schell et al., 1995).

Electron microscopy. Vibratome sections $(50 \mu \mathrm{m})$ were prepared as for light microscopy, except that Triton X-100 was omitted from the primary antibody incubation. After visualization of the labeling with diaminobenzidine, sections were incubated in $1 \%$ osmium tetraoxide $/ 0.1 \mathrm{M}$ sodium phosphate for $90 \mathrm{~min}$, washed in water, and then incubated for $45 \mathrm{~min}$ in $1.5 \%$ uranyl acetate. Sections were washed again in water and dehydrated in graded ethanols, followed by propylene oxide, and then equilibrated overnight in increasing concentrations of Medcast-Aldralite 502 (Ted Pella, Inc., Redding, CA). Sections were embedded flat between acetate sheets, polymerized overnight, and examined with light microscopy to identify regions of interest; these were excised and mounted flat in plastic capsules. Semithin $(1 \mu \mathrm{m})$ sections were cut and placed onto slides and examined; well-stained regions were identified by light microscopy and trimmed before $70 \mathrm{~nm}$ sections were cut and placed onto 200-mesh copper grids. To maximize contrast between stained and unstained areas, grids were not counterstained before being viewed with a Zeiss EM10 electron microscope at $80 \mathrm{kV}$ with a large objective aperture.

HPLC analysis. Whole cerebella were sonicated in $10 \mathrm{vol}$ of ice-cold $5 \%$ trichloroacetic acid and centrifuged to remove protein. Soluble fractions were extracted three times with water-saturated ether before HPLC analysis of amino acid enantiomers as described (Hashimoto et al., 1992b).

\section{RESULTS}

Although the glycine binding site is present on the NR1 subunit (Moriyoshi et al., 1991; Lynch et al., 1994), NMDA receptor channels exist physiologically as multimers composed of NR1 and one or more of the other subtypes (Kutsuwada et al., 1992; Meguro et al., 1992; Monyer et al., 1992). The vast majority of NMDA receptors in the forebrain include NR2A and/or 2B subtypes, and previous localization studies (Watanabe et al., 1992; Monyer et al., 1994) show that these subtypes most closely resemble D-serine binding sites (Schell et al., 1995). To visualize functional NMDA receptors most likely to be modulated by D-serine in vivo, we have used an antibody specific for subtypes $2 \mathrm{~A}$ and $2 \mathrm{~B}$.

\section{D-Serine and NR2A/B display similar locations throughout the forebrain}

In 21-d-old rats, both D-serine and NR2A/B are concentrated in the gray matter of the telencephalon (Fig. 1, top and middle). In the cerebral cortex, D-serine staining appears patchy and is most abundant around blood vessels. D-Serine staining is observed in all cortical layers but is concentrated in deeper regions. Intense labeling is apparent in the amygdaloid nuclei and the claustrum. The intense cortical staining for NR2A/B concentrates in the frontal and parietal lobes and appears layered, with densest labeling in layers II-IV. NR2A/B staining is also dense in cortical layer I, the temporal lobes, the piriform cortex, and amygdala. Higher-power examination of the amygdala (Fig. 2, top and middle) confirms that both $\mathrm{D}$-serine and NR2A/B concentrate in this region, with the $\mathrm{D}$-serine in astrocytes and NR2A/B in pyramidal neurons. Glycine staining in the amygdala is extremely low by comparison and has a pattern that is a virtual negative image of that for NR2A/B (Fig. 1, bottom). The most intense staining for glycine occurs in the hindbrain and hypothalamus, two regions where NR2A/B is in low abundance. In the olfactory bulb, hindbrain, and spinal cord, we readily observe the known inhibitory glycinergic pathways (Campistron et al., 1986; van den Pol and Gorcs, 1988; Pourcho et al., 1992).

Throughout the subiculum and hippocampus (Fig. 3), high densities of D-serine occur in molecular layers. The stratum radiatum, the area with the highest density of NMDA receptor associated D-serine binding sites in brain (Schell et al., 1995), contains an abundance of D-serine. The pyramidal cell layers are unstained, as is the granule cell layer of the dentate gyrus. The molecular layer of the dentate gyrus, especially the lower blade region, is stained densely, as is the hilus. Similar to D-serine, dense staining for NR2A/B is observed in molecular layers of the subiculum and CA1 and CA3 regions. The pyramidal cell layers are also densely labeled, but the granule cells of the dentate gyrus are not. The hilus and inner third of the dentate gyrus molecular layer are weakly stained, whereas the outer two thirds is strongly stained. Glycine staining is generally low in the hippocampus, especially in the CA1 region, and is localized differently than NR2A/B. Two discrete bands of higher glycine density are observed. One is in the stratum lucidum of the CA3 region, associated with terminals of the mossy fibers. The other is in the deep hilus, including a dense, thin layer just inside the dentate granule cells. Both regions are notable for their very low densities of NMDA receptors relative to other areas of the hippocampus (Cotman et al., 1987), and long-term potentiation at the mossy fiber synapses is presynaptic and does not involve NMDA receptors (Zalutsky and Nicoll, 1990). Overall, glycine in the hippocampus is distributed virtually the opposite of NR2A/B, although substantial labeling for both is observed in the outer third of the dentate gyrus molecular layer.

In certain brain regions outside of telencephalic gray matter, NR2A/B and D-serine are not similarly localized, or NR2A/B localizations more closely resemble glycine than D-serine. For example, D-serine is present in a band of subcallosal white matter that includes the alveus and the subependymal zone (Fig. 1, top arrows), where NR2A/B is not detected. NR2A/B labeling is dense in the substantia nigra pars reticulata, where $\mathrm{D}$-serine staining is weak and glycine staining is intense.

\section{Olfactory bulb contains both $\mathrm{D}$-serine and glycine}

The highest densities of D-serine staining in the brain occur in the nerve layer of the accessory olfactory bulb (AOB), which is composed of unique glia that ensheath incoming axons from the vomeronasal organ. NR2A/B occurs in this layer, as reported previously for NR1 (Petralia et al., 1994b), as well as moderate glycine labeling. In the $\mathrm{AOB}$, the most intense NR2A/B staining occurs in the plexiform layer, in the dendrites of mitral cells. Both D-serine and glycine are observed in this layer, with D-serine found in astrocytes and glycine concentrated around mitral cell dendrites and cell bodies. The AOB is notable because it is one of only a few brain regions with high densities of D-serine and glycine together.

D-serine staining in the main olfactory bulb is much lower than in the telencephalon, but its layering pattern resembles NR2A/B. Both are most concentrated in the external plexiform layer. D-Serine concentrates in protoplasmic astrocytes near mitral and tufted cell dendrites, which are intensely stained for NR2A/B (Petralia et al., 1994a). Lesser amounts of both D-serine and NR2A/B occur in the periglomerular region, olfactory nerve layer, and inner plexiform layer. In the inner plexiform layer, 


\section{D-SERINE}
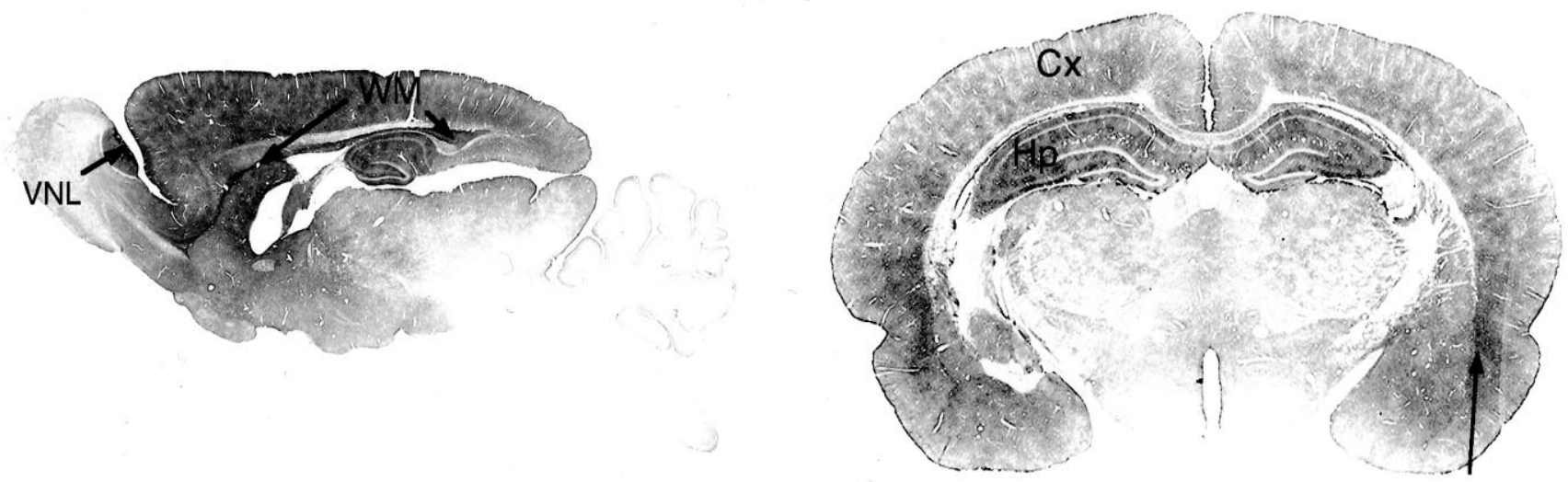

$\mathrm{Cl}$

\section{NR2A/B}
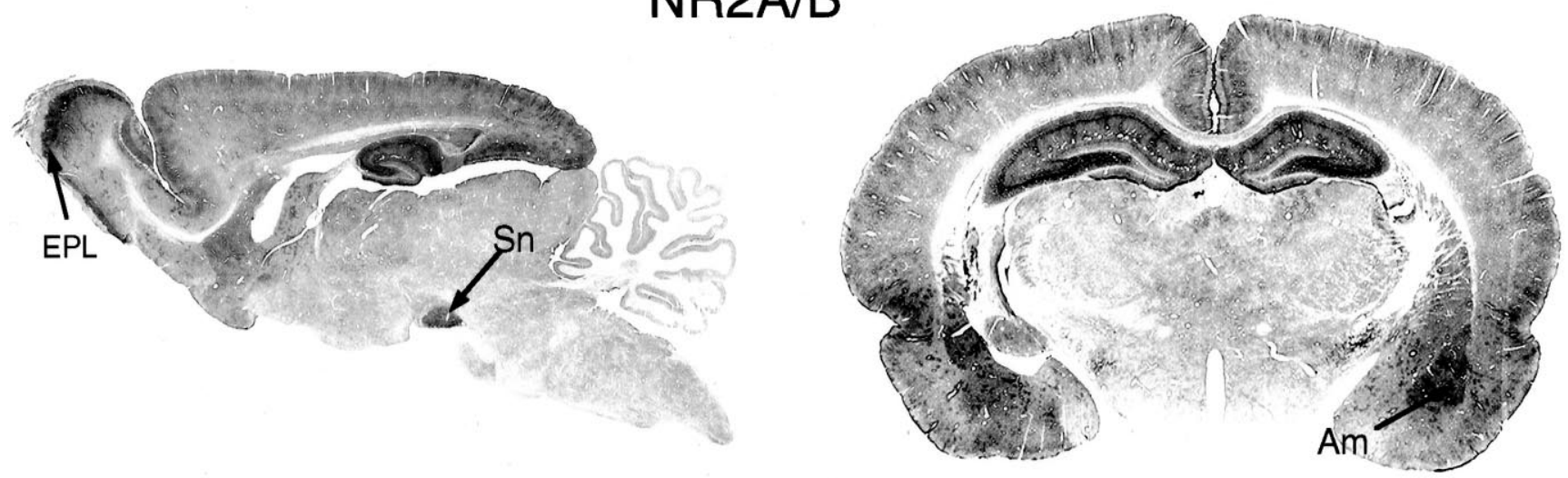

\section{GLYCINE}
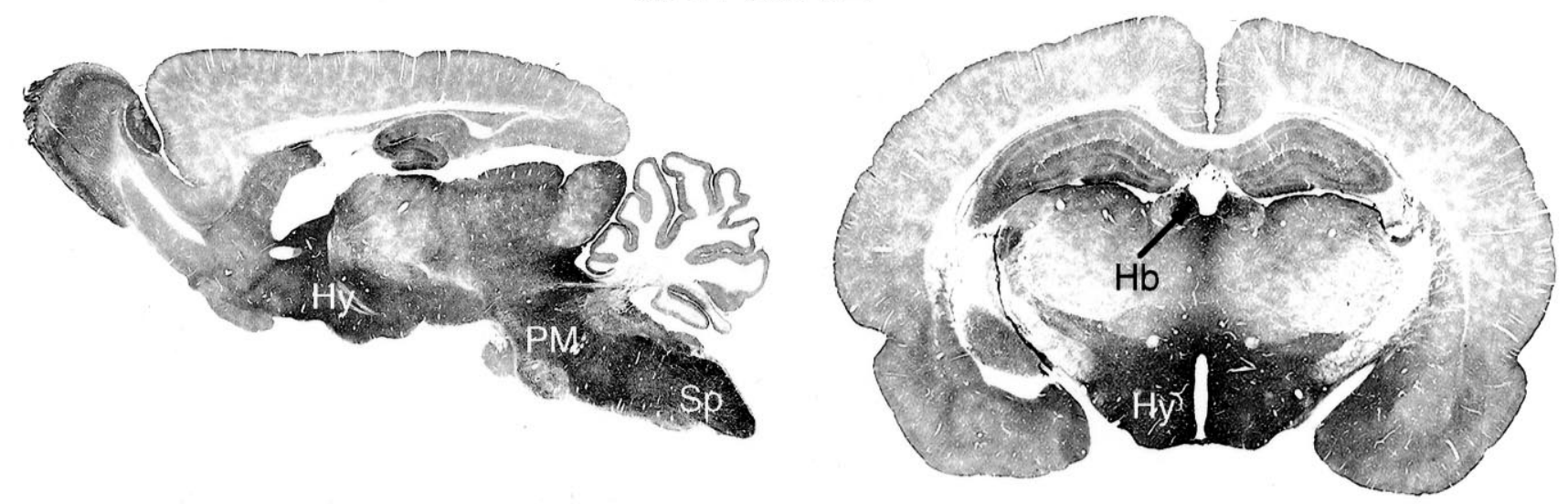

Figure 1. P21 serial brain sections stained for D-serine, NR2A/B, or glycine. $A m$, Amygdala; $C l$, claustrum; $C x$, cortex; $E P L$, external plexiform layer; $H b$, habenula; $H p$, hippocampus; $H y$, hypothalamus; $P M$, pons/medulla; $S n$, substantia nigra; $S p$, spinal cord; $W M$, white matter; $V N L$, vomeronasal nerve layer.

NR2A/B appears as scattered dots. D-Serine also occurs in the ependymal layer, where NR2A/B is not detected. We observe high densities of glycine staining in all layers of the main olfactory bulb, especially the external plexiform layer, as reported previously (van den Pol and Gorcs, 1988). Glycine is an inhibitory transmitter in this region, and most olfactory bulb neurons, especially mitral and tufted cells, express strychnine-sensitive glycine receptors (Trombley and Shepherd, 1994). Glycine staining is densely concentrated in neuropil surrounding mitral cell bodies and proximal processes, but is not inside mitral cell somata. Glycine is also prominent in periglomerular cells. Thus, in the main olfactory bulb, glycine appears enriched near both inhibitory and excitatory glycine receptors.

\section{Cellular and ultrastructural localization of D-serine and NR2A/B in hippocampal CA1 region}

We focused on the hippocampus for a more detailed description of the relationship between D-serine and NR2A/B, because it has 

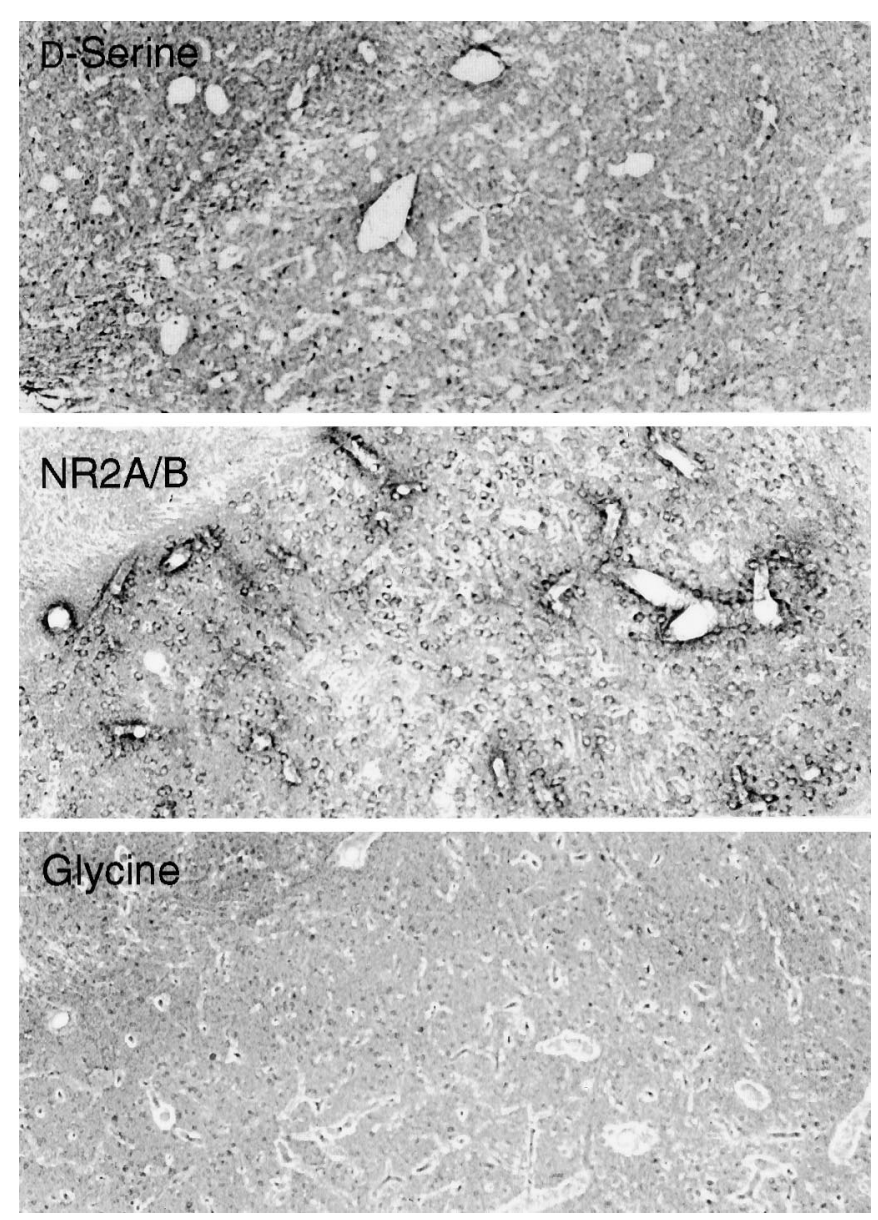

Figure 2. P21 amygdala stained for D-serine, NR2A/B, or glycine. Both D-serine and NR2A/B appear concentrated near blood vessels.

one of the highest D-serine-to-glycine ratios (Hashimoto et al., 1993b), and densities of D-serine binding sites in the CA1 molecular layers are the highest in brain (Schell et al., 1995). Figure 4 reveals the overlapping distributions of D-serine and NR2A/B in the stratum radiatum of the CA1 region of hippocampus. D-Serine is concentrated in the cell bodies and processes of glia, which are prominent throughout all molecular layers and also in the overlying white matter. The densest staining for D-serine occurs in glia processes surrounding blood vessels (Fig. 4C), whereas the densest staining for NR2A/B occurs around the base of the pyramidal cell dendrites. In neuronal layers, $\mathrm{D}$-serine-containing processes of glial cells course between neuronal cell bodies (Fig. 4C), which are densely labeled for NR2A/B. In contrast, the very light glycine staining in CA1 is restricted to widely scattered cell bodies in the molecular layer, which resemble small interneurons or glia.

At the ultrastructural level, we confirm the similar localizations of $\mathrm{NR} 2 \mathrm{~A} / \mathrm{B}$ and $\mathrm{D}$-serine. In the stratum radiatum of CA1, $\mathrm{D}$-serine is most concentrated in astrocytic foot processes, which abut unstained endothelial cells and pericytes (Fig. 5, left). Immunoreactivity appears as black clumps throughout the cytosolic matrix but not in mitochondria. High densities of D-serine are also observed in the thin glial elements of neuropil known to surround the dendrites and spines of neurons. No structures that can be identified definitively as neurons are labeled for D-serine. Labeling for NR2A/B is strong in many neurons, especially in dendritic spines (Fig. 5, right), as reported previously (Petralia et al., 1994a).
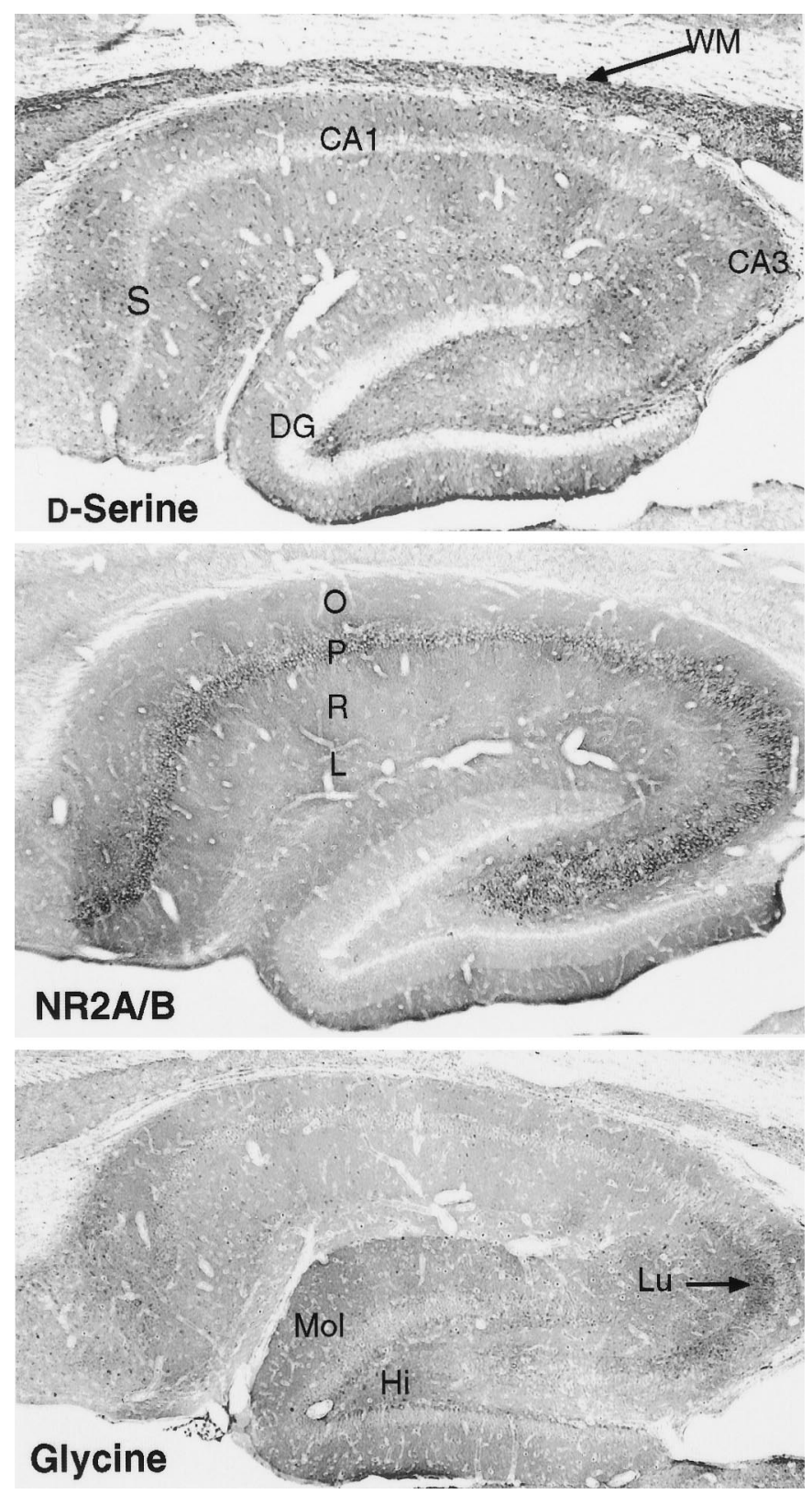

Figure 3. P21 hippocampus stained for D-serine, NR2A/B, or glycine. $D G$, Dentate gyrus; $H i$, hilus; $L$, stratum lacunosum molecular; $L u$, stratum lucidum of CA3 region; $\mathrm{Mol}$, molecular layer of dentate gyrus; $O$, stratum oriens; $P$, stratum pyramidale; $R$, stratum radiatum; $S$, subiculum; $W M$, white matter.

\section{D-Serine and NR2A/B have parallel ontogeny in the cerebellum}

We observed previously that D-serine staining in the cerebella of 50-d-old rats is much lower than in the forebrain and is restricted to the molecular layer (Schell et al., 1995). Biochemical assays indicate high levels of D-serine in the cerebella of juvenile rats (Hashimoto et al., 1995a). We monitored cerebellar levels of $\mathrm{D}$-serine and glycine during the first 3 postnatal weeks (Fig. 6). D-Serine is detectable at birth and remains at a level of $\sim 0.1 \mu \mathrm{mol} / \mathrm{gm}$ until the end of week 1 . During week 2, levels more than double, reaching a peak of $\sim 0.25 \mu \mathrm{mol} / \mathrm{gm}$ at P12. D-Serine levels then decline, reaching undetectable levels by P26. Levels of glycine exceed those of D-serine at all ages, 


\section{D-SERINE}

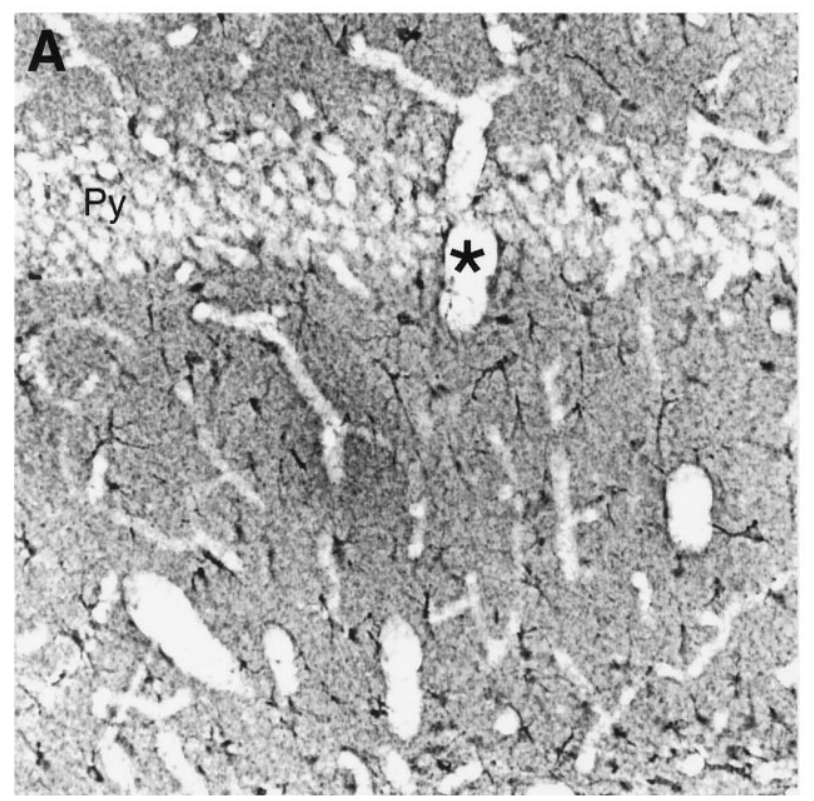

NR2A/B
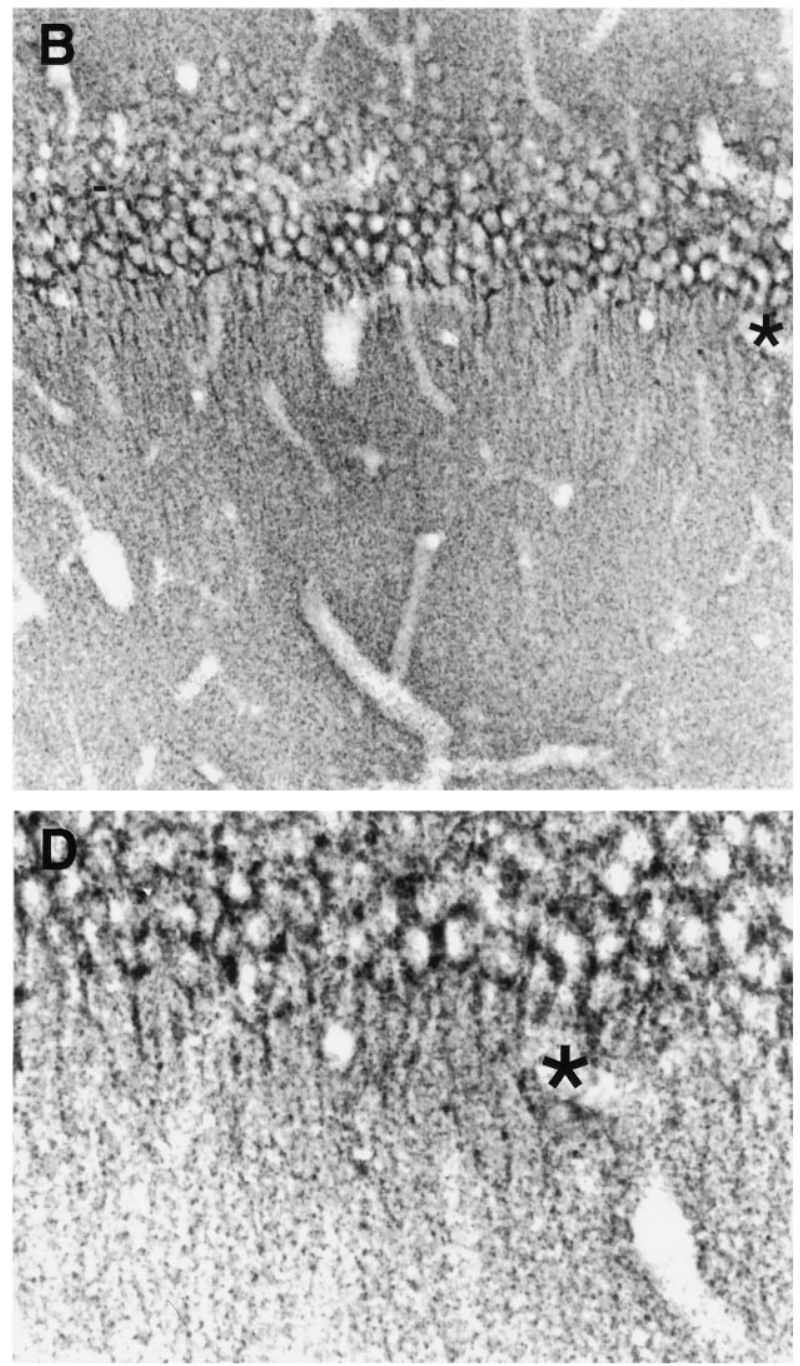

Figure 4. Detailed comparison of D-serine and NR2A/B in P21 hippocampal CA1 region. $A$, $B$, D-Serine concentrates in the glia of molecular layers, especially near blood vessels (asterisks), whereas NR2A/B is found in pyramidal neurons and all layers of neuropil. $C, D$, Higher-power magnification of regions near blood vessels.

with a surprisingly large rat-to-rat variation: between 0.5 and $0.9 \mu \mathrm{mol} / \mathrm{gm}$. Unlike D-serine, substantial amounts of glycine are detected in mature rats.

Immunohistochemical analysis confirms and extends these findings (Fig. 7). At P7, D-serine is concentrated in glial cell bodies scattered throughout the white matter, deep nuclei, inner granule cell layer, and the growing molecular layer. NR2A/B staining is observed in the deep nuclei, and the first indications of labeling in Purkinje cell bodies appear around this age. Strongly glycinergic Golgi neurons appear to have moved upward from deep layers and localize to the inner granule layer by P7 (not shown).

By P14, staining for D-serine is diminished in the deep nuclei, remains in the deep white matter, and has become stronger in the processes of multipolar glia scattered in the inner granule cell layer. Even more striking are the Bergmann glia in the molecular layer, which stain intensely in their cell bodies and radial processes. The outer granule layer is unstained, except for fine radial glial processes, which extend to the pia. At P14, NR2A/B has disappeared from the deep nuclei and become prominent in the cell bodies and dendrites of the Purkinje cells extending into the growing molecular layer. Also, a few large NR2A/B neurons appear scattered in the inner granule layer at this age; these are likely to be Golgi neurons. We observe no NR2A/B staining in inner or outer granule cell bodies. By P14, the cellular pattern for glycine resembles the adult, with intense staining in Golgi cells and lesser staining in a subset of basket cells; however, staining of the molecular layer appears substantially lower than in the adult.

By the end of week 3, the distributions of D-serine and NR2A/B begin to take on their adult patterns. D-serine labeling at P21 is greatly reduced compared with that at P14 and is observed mainly in Bergmann glia cell bodies and thin radial processes, although some lightly stained glial cells are still observed in the granule cell layer. NR2A/B remains detectable in Purkinje cells in the molecular layer but has receded from the more distal dendrites. Around P21 we also observe the first labeling of the pinceau, the axon terminals of the basket cells, which form a loose plexus around the proximal dendrites of Purkinje cells. Although some reports suggest that migrating granule cells transiently express NR2A/B 

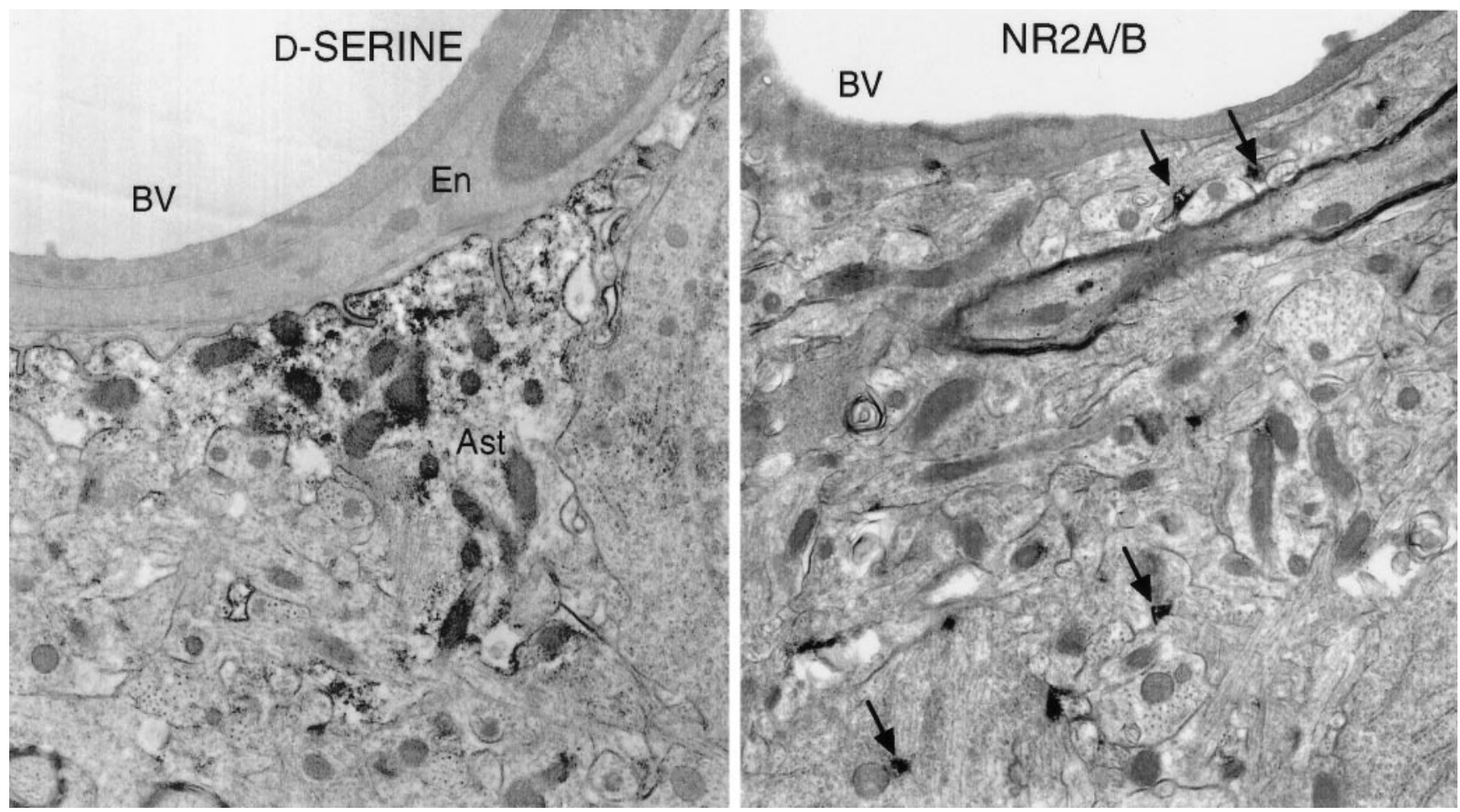

Figure 5. Ultrastructural comparison of D-serine and NR2A/B in hippocampal CA1 region. Brain sections were stained with the immunoperoxidase technique and then processed for electron microscopy. D-Serine concentrates in the cytosolic matrix of astrocytes (Ast) in neuropil and in foot processes ensheathing blood vessels $(B V)$, whereas endothelial cells $(E n)$ are unstained. NR2A/B concentrates in dendritic spines $($ arrows $)$. 10,000 $\times$ magnification.

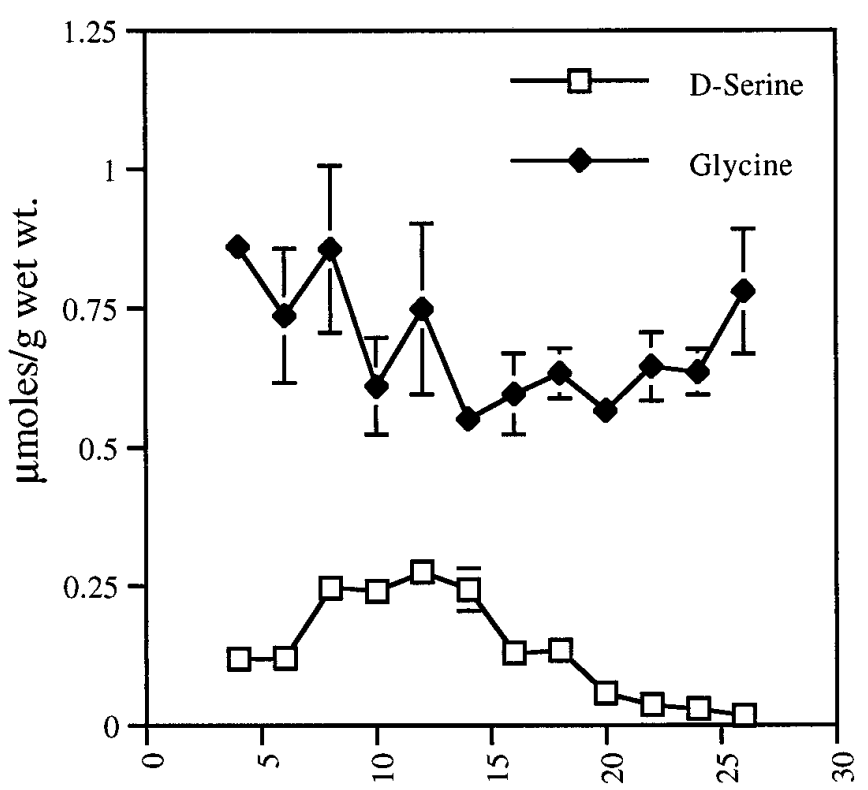

Postnatal day

Figure 6. Levels of free D-serine and glycine in cerebellum during postnatal development. Cerebella were analyzed by HPLC for free amino acids. Values are mean $\pm \mathrm{SEM} ; n=3$.

receptors (Farrant et al., 1994), we do not observe any granule cells labeled with the NR2A/B antibody. Glycine labeling at P21 resembles $\mathrm{P} 14$, except that many more immunoreactive punctate nerve processes fill the molecular layer; these are probably dendrites of Golgi and basket cells.
In the adult cerebellum (Fig. 8, right), weak staining for D-serine is observed only in Bergmann glia. In some cases, staining is concentrated in the cell bodies located between Purkinje cells at the inner edge of the molecular layer. In other cases, small groups of Bergmann glia appear instead to be stained preferentially in their distal processes. Low levels of NR2A/B immunoreactivity can be detected in some but not all Purkinje cell bodies through the second month of postnatal life. We observe no labeling of adult granule cells, which express the NR2C subunit. In mature adults, labeling for NR2A/B appears to be restricted absolutely to basket cell pinceau, many of which are also strongly immunoreactive for glycine (Fig. 8).

\section{DISCUSSION}

In the present study we confirm and extend substantially our initial finding that D-serine is localized in rat brain to astrocytes that are selectively concentrated in the gray matter, with a distribution closely resembling that of NMDA receptors, specifically the NR2A/B subtypes; these are the principal subtypes of NMDA receptors in the forebrain, the area of greatest NMDA receptor density. In the CA1 region of the hippocampus, where NMDA receptor neurotransmission is prominent, D-serine-containing astrocytes are found in close proximity to the NR2A/B-enriched dendrites of pyramidal cells, consistent with a role for D-serine in regulating the glycine site of these receptors during long-term potentiation (Fig. 9, left).

In our earlier study we mapped D-serine in 50-d-old rats, whereas the present study used 21-d-old rats. Although the great majority of the D-serine localizations are the same at the two ages, we observe some discrete differences. At P21 we observe prominent $\mathrm{D}$-serine staining in a subcallosal band of white matter just superficial to the hippocampus, which is greatly diminished in P50 


\section{D-SERINE}
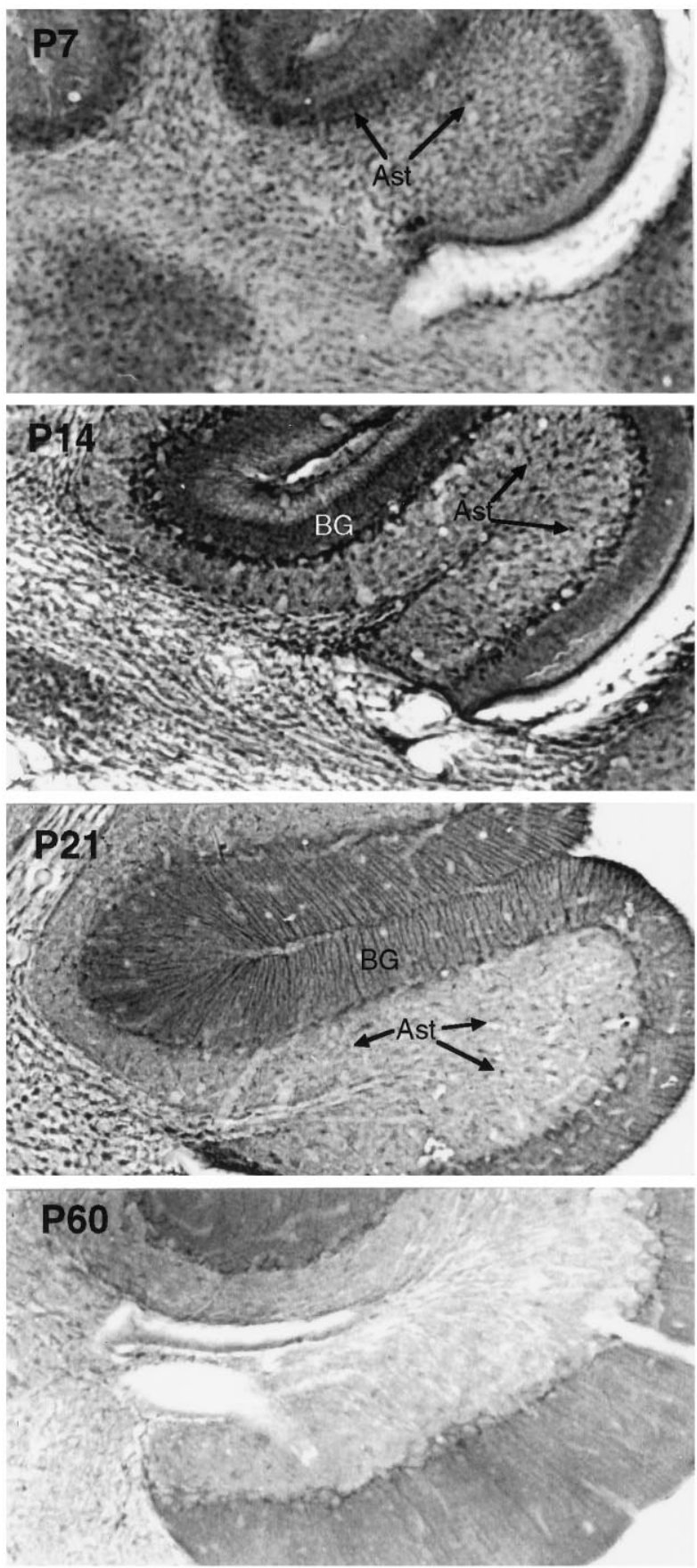

NR2A/B
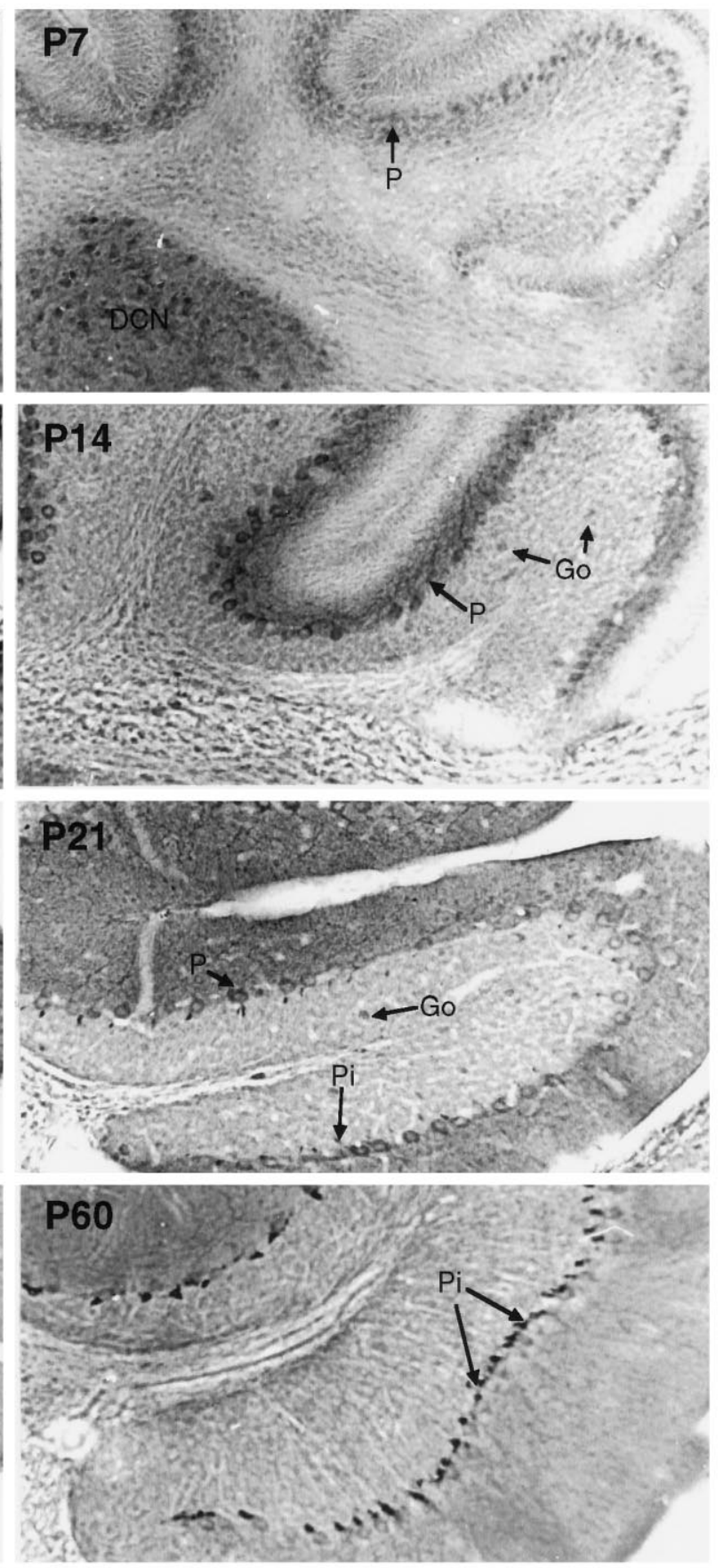

Figure 7. Transient staining for D-serine and NR2A/B in developing cerebellum. The cell bodies of D-serine glia (Ast) are well labeled by P7, when Purkinje cells $(P)$ begin to stain for NR2A/B. One week later, both D-serine and NR2A/B concentrate in the molecular layer, with D-serine in Bergmann glia $(B G)$ and NR2A/B throughout the dendritic tree of Purkinje cells. In the P14 granule layer, many protoplasmic astrocytes stain intensely for D-serine, whereas a few Golgi neurons (Go) are lightly stained for NR2A/B. By P21, staining for both has decreased, but substantial amounts of D-serine persist in the radial process of BG and in the cell bodies of protoplasmic astrocytes (Ast). NR2A/B at P21 has become less prominent in Purkinje cells and has appeared in some basket cell pinceau $(\mathrm{Pi})$. In mature adults, D-serine occurs weakly in Bergmann glia cell bodies, whereas NR2A/B is restricted to basket cell pinceau.

animals. This intensely stained area is demarked caudally by the splenium of the corpus callosum and extends rostrally to the subcallosal regions of the striatum and subependymal layer. These are regions of active cell proliferation and migration in young adults. In older rats, D-serine is more abundant in superficial as contrasted to deeper layers of the cerebral cortex. We have obtained evidence that these variations relate to the migration of astrocytes from the site of their initial proliferation and migration in subcortical white matter near the subventricular zone to their localization in the gray matter of mature brain (M. J. Schell and 


\section{D-Serine}

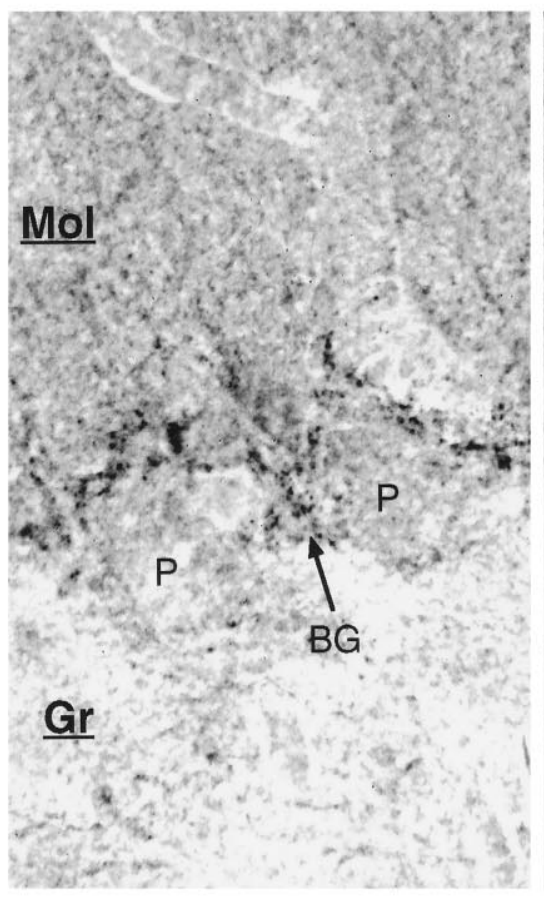

$\mathrm{NR} 2 \mathrm{~A} / \mathrm{B}$

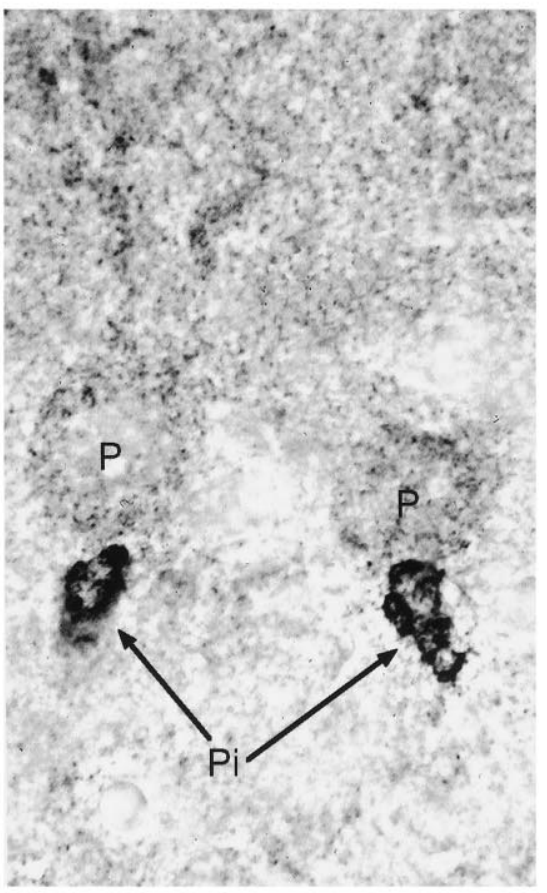

Glycine

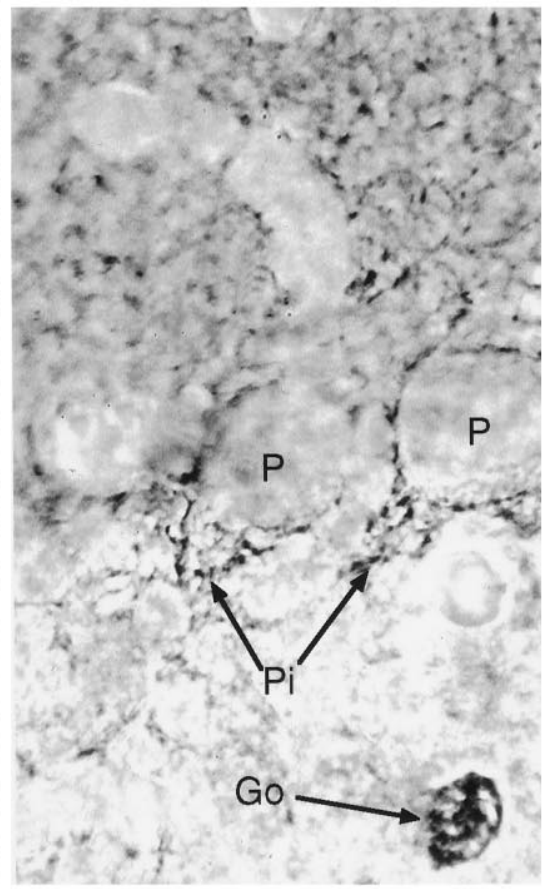

Figure 8. High magnification of adult cerebellum near Purkinje cell bodies. D-Serine is restricted to Bergmann glia $(B G)$ in the molecular layer $(M o l)$, especially in glial cell bodies that reside between Purkinje cells $(P)$. The granule layer $(G r)$ is not stained for D-serine. NR2A/B still occurs in a minority of Purkinje cell dendrites, but the most intense staining occurs in basket cell pinceau (Pi), which also stain for glycine. Golgi neurons (Go), whose cell bodies reside in the granule layer, are the major glycinergic element of the cerebellum.

S. H. Snyder, unpublished observations). The antibody to NR2A/B used in this study was developed and used extensively in a previous study (Petralia et al., 1994a). The labeling patterns we obtain are in generally good agreement with this work, with the modest differences explained by our use of younger animals and a high-glutaraldehyde fixative. When we stain P50 animals using the fixative of Petralia et al., (1994a), we faithfully reproduce their results.

Glycine localizations differ dramatically from those of D-serine and NR2A/B and instead resemble cloned glycine transporters (Zafra et al., 1995; Jursky and Nelson, 1996), with very low or undetectable levels in hippocampus and cortex. Glycine is localized inversely to the glycine cleavage enzyme, which is enriched in the mitochondria of telencephalic gray matter astrocytes (Sato et al., 1991). Autoradiographic studies of hippocampus slices have demonstrated that glycine is taken up into astrocytes (Fedele et al., 1993), where the degradation of two glycine molecules produces serine (Daly et al., 1976). This pathway may be relevant to D-serine synthesis, because D-serine is probably concentrated in many of the same protoplasmic astrocytes, and the ontogeny of glycine cleavage activity in cerebellum (Lahoya et al., 1980) closely follows that of D-serine (Fig. 6). On the other hand, we do not observe D-serine staining in mitochondria, where the glycine cleavage enzyme is thought to be localized exclusively.

At the ultrastructural level, D-serine is concentrated in astrocyte foot processes. The hippocampal CA1 region contains high densities of D-serine in the cytosolic matrix of glia, which ensheath NR2A/B-enriched spines as well as blood vessels. Non-NMDA receptors are present in astrocyte end feet (Matute et al., 1994) and are well positioned to regulate D-serine release. D-Serine staining at the ultrastructural level strongly resembles staining for glycogen phosphorylase, the enzyme of the cytosolic matrix that controls glycogen breakdown (Richter et al., 1996). The preferential glycolytic activity of astrocytes is reflected by their almost exclusive ability to make and store glycogen in brain. It is thought that glucose from blood enters astrocytes, whose glycolysis leads to the formation of metabolic substrates in the cytosol, such as lactate, that pass into nearby dendrites to facilitate Krebs cycle metabolism (Tsacopoulos and Magistretti, 1996). How metabolic coupling might influence D-serine synthesis or release is unclear. NMDA receptor-mediated neurotransmission may occur in neuropil near blood vessels, with the high demand for energy during excitatory neurotransmission fueled by rapid exchange of metabolites through astrocytes. Astrocytic D-serine would activate glycine sites on the spines of neurons near blood vessels to regulate this process.

The highest densities of D-serine in the brain occur in the AOB, in specialized glia that surround axons of the vomeronasal fibers that project from the vomeronasal organ to olfactory glomeruli (Raisman, 1985; Ramon-Cueto and Valverde, 1995). This fiber system mediates the actions of pheromones on reproductive behavior (Halpern, 1987). Olfactory nerve layer glia promote the growth of primary receptor neuron axons and allow the reestablishment and maintenance of connections with the olfactory bulb (Raisman, 1985). Olfactory nerve layers stain moderately for NR1 (Petralia et al., 1994b), and we detect NR2A/B in both main and accessory nerve layers. NMDA receptors promote and regulate neurite outgrowth (Zheng et al., 1996) and play crucial roles in the establishment of neuronal connectivity throughout the brain. If glutamatergic transmission occurs among the thin, unmyelinated 

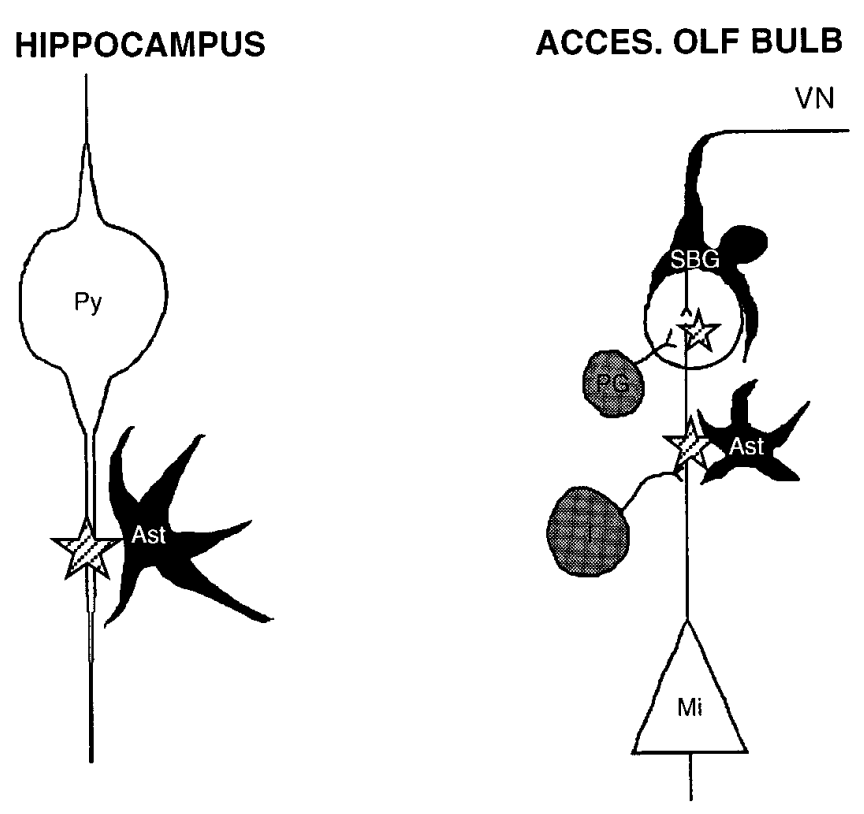

Figure 9. Models depicting the proposed modulatory roles for D-serine and glycine in the CA1 region of hippocampus (left) and the AOB (ACCES. OLF BULB, right). D-Serine is black; glycine is gray. Stars indicate localizations of NMDA receptors. In the hippocampus, D-serinecontaining protoplasmic astrocytes $(A s t)$ are localized near NMDA receptors located on pyramidal cell $(P y)$ dendrites, whereas glycinergic cells are rare. In the $\mathrm{AOB}$, both $\mathrm{D}$-serine and glycine appear concentrated near NMDA receptors located on mitral cells $(M i)$, with the D-serine found in superficial bulbar glia $(S B G)$ surrounding the vomeronasal nerve $(V N)$ and in protoplasmic astrocytes $(A s t)$ in the plexiform layer. Glycine concentrates in interneurons $(I)$ and periglomerular cells $(P G)$.

neurites inside the vomeronasal nerve layer, then D-serine released from the superficial bulbar glial cells would excite NMDA receptors on primary receptor axons within the nerve. In and near glomeruli, glial-derived D-serine would modulate NMDA receptors located on dendrites of mitral or tufted cells (Ennis et al., 1996) and regulate synaptic connectivity (Fig. 9, right).

\section{Ontogenic roles of D-serine in the cerebellum}

NMDA receptors are expressed transiently on Purkinje cells but are absent from adults (Dupont et al., 1987; Garthwaite et al., 1987). The transient staining we observe probably reflects the NR2B subtype (Watanabe et al., 1994; Portera-Cailliau et al., 1996). Between P5 and P15, parallel fibers and climbing fibers establish connections with Purkinje cells (Altman, 1972). NMDA receptors are required for proper synapse formation and elimination, because blockers of NMDA receptors prevent the establishment of normal connectivity (Rabacchi et al., 1992). During this critical period, Bergmann glia are intensely stained for D-serine, and the processes of these cells envelop the Purkinje cell dendritic tree (Palay and Chan-Palay, 1974). After the critical period, D-serine levels drop rapidly, because Bergmann glia begin expressing D-amino oxidase (Weimar and Neims, 1977a,b; Horiike et al., 1987). Therefore, astrocytic D-serine is both spatially and temporally positioned to modulate NMDAR-dependent synaptogenesis with Purkinje cells (Fig. 10, left).

Another prominent feature of cerebellar development is the migration of the granule cells from the external to the internal granule cell layers along the processes of Bergmann glia, which serve as a scaffold. This migration is dependent on NMDA receptors being blocked by the NMDAR antagonist MK801 and stim- ulated by glycine (Komuro and Rakic, 1993; Rossi and Slater, 1993). Starting around P7, radial processes of D-serine-producing Bergmann glia appear in the molecular layer, coincident with the migration of granule cells. Low levels of glycine staining also occur in proximity to migrating granule cells, in the dendrites of Golgi neurons; however, the Golgi cell staining becomes more intense at the end of week 3, after granule cell migration is completed. D-Serine in the radial processes of Bergmann glia is the better candidate regulator for glycine sites involved in granule cell migration.

In the inner granule layer, NMDA receptors are present on the dendrites of granule cells at synapses with mossy fibers (D'Angelo et al., 1993). Synaptogenesis here occurs during a critical period, approximately P8-28 (Garthwaite and Brodbelt, 1989). During this period, mossy fiber synapses segregate into rosettes with granule cell dendrites to form glomeruli. D-Serine occurs transiently in the granule layer, in the cell bodies and processes of protoplasmic astrocytes in close vicinity to glomeruli. Astrocytes are believed to be involved in the compartmentalization and segregation of glomerular units (Palay and Chan-Palay, 1974), and glial D-serine could help define the boundaries of each unit (Steindler, 1993).

The glomerular synapse is also believed to be where NMDA neurotransmission stimulates granule cells to produce nitric oxide. In P5-14 cerebellar slices, glycine sites involved in nitric oxide production are saturated, because exogenously added D-serine does not enhance cGMP production (Southam et al., 1991). Beginning around P21, these glycine sites are not saturated, because the NMDA-stimulated cGMP response is enhanced by exogenous D-serine. In adult cerebellum, in vivo studies have demonstrated that the glycine site involved in nitric oxide production is not saturated (Wood et al., 1989). We find that D-serine levels in the P7-14 cerebellum are 10-40 times higher than in adults. The production of astrocytic D-serine and its subsequent destruction by D-amino acid oxidase concentrated near glomerular synapses (Weimar and Neims, 1977a,b) seems to account for the change in glycine site saturation. D-Serine release from astrocytes is not stimulated by $\mathrm{KCl}$ depolarization, but rather occurs by stimulation of non-NMDA receptors and sodium-dependent transporter-reversal (Schell et al., 1995). The endogenous glycine site agonist regulating nitric oxide production in cerebellum acts in a tetrodotoxin (TTX)-independent manner during development, but in a TTX-dependent manner in adults (Southam et al., 1991). The principal glycinergic cell in the cerebellum is the Golgi neuron (Ottersen et al., 1988). These data are consistent with a model by which glomerular synapses are established through mechanisms involving the release of D-serine from astrocytes but are modulated in adults by glycine released by Golgi neurons (Fig. 10).

In adult cerebellum, the principal NMDA receptor subtype is $2 \mathrm{C}$, located on granule cell dendrites. Glycine seems to be the endogenous agonist of this receptor in the adult, with D-serine present at very low levels only in Bergmann glia. Glycine coexists with GABA in Golgi neurons (Ottersen et al., 1988), consistent with a role as an inhibitory neurotransmitter. Yet glycine binding in the cerebellum is strychnine-insensitive (Wilkin et al., 1981). It is well established that Golgi neuron terminals release GABA at glomeruli and inhibit the mossy fiber/granule cell synapse (Palay and Chan-Palay, 1974). Glycine co-released with GABA instead may activate or shape the NMDA receptor response of granule cells.

NR2A/B in adult cerebellum occurs almost exclusively in the 

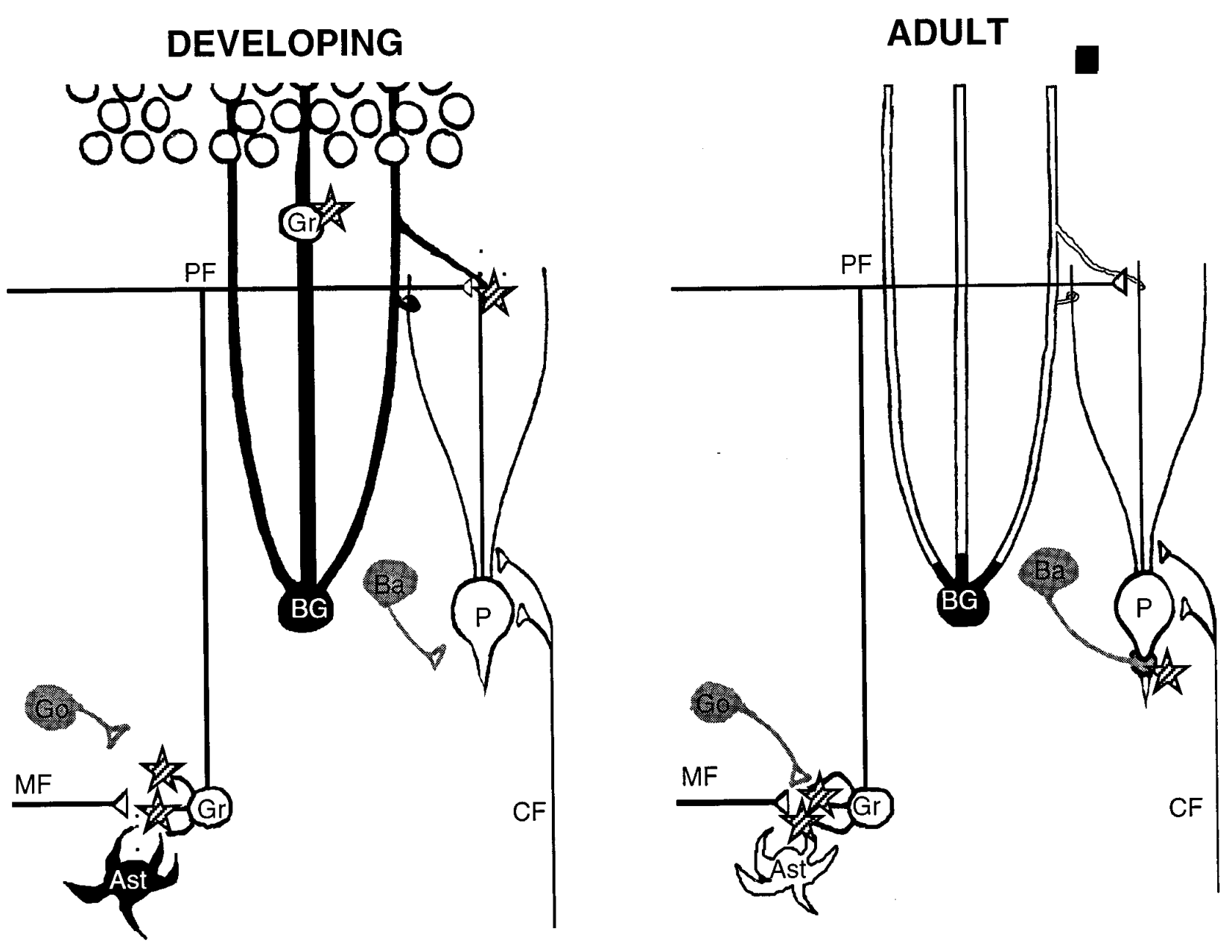

Figure 10. Models contrasting the proposed roles for D-serine and glycine in developing and adult cerebellum. D-Serine is black; glycine is gray. Stars indicate localizations of NMDA receptors. In developing molecular layer (left), astrocytic D-serine is found in Bergmann glia (BG), which ensheath Purkinje cells expressing NMDA receptors and also guide migrating granule cells $(G r)$ expressing NMDA receptors. D-Serine released from Bergmann glial processes might synergize with glutamate released by parallel fibers $(P F)$ and climbing fibers $(C F)$. In the developing inner granule layer, protoplasmic astrocytes $(A s t)$ might release D-serine near the developing glomerular synapse to synergize with glutamate from mossy fibers $(M F)$, whereas glycinergic basket $(B a)$ and Golgi neurons $(G o)$ have not yet established connections with NMDA receptor-containing synapses. In contrast, in adult cerebellum (right), no D-serine is present, and NMDA receptors have disappeared from Purkinje cells. NMDA receptor-associated glycine sites located on the basket cell pinceau and granule cells might be modulated exclusively by glycinergic basket $(B a)$ and Golgi $(G o)$ neurons.

pinceau structures composed of basket cell terminals surrounding the initial segments of Purkinje cells (Fig. 8). Glycine-containing terminals are concentrated in these pinceau, which also contain GABA (Liu et al., 1989). What glutamatergic fibers are most likely to activate NMDA receptors located on basket cell terminals? Tendril collaterals of climbing fibers project to Purkinje cell bodies near their axons (Palay and Chan-Palay, 1974). Physiological studies have demonstrated that glutamate or aspartate from parallel fibers acts on NMDA receptors located on basket cell dendrites to increase GABA release, because the application of NMDA onto adult cerebellar Purkinje cells produces inhibitory responses that are blockable by bicuculline (Crepel et al., 1982; Quinlan and Davies, 1985; Llano et al., 1991). Climbing fiber tendril collaterals near NMDA receptors on basket cell axons could mediate a similar response.

Some researchers have suggested that endogenous levels of glycine are sufficient to fully saturate the glycine site of NMDA receptors. Because D-serine levels in the extracellular space of many brain regions are similar to those of glycine (Hashimoto et al., 1995b), the same could be said for D-serine. Moreover, D-serine is about three times more potent than glycine at many "glycine sites," so lower levels of D-serine would suffice to saturate the sites. A substantial number of studies suggest that glycine sites are not always saturated, because exogenous $\mathrm{D}$-serine and glycine potentiate responses to NMDA in vivo (Salt, 1989; Wood et al., 1989; Thiels et al., 1992; Schmitt et al., 1995). Moreover, pretreating intact rats with D-serine increases the potency of exogenous NMDA as a convulsant (Larson and Beitz, 1988; Singh et al., 1990).

D-Serine fulfills the principal criteria for a neuromodulator at the glycine site of NMDA receptors. It is localized at these sites and faithfully mimics actions of the endogenous ligand. We showed previously that $\mathrm{D}$-serine is released by glutamatergic stimulation. $\left[{ }^{3} \mathrm{H}\right] \mathrm{D}-$ Serine is accumulated into cerebral cortical synaptosome preparations and type II astrocyte cultures only $\sim 5 \%$ as well as $\left[{ }^{3} \mathrm{H}\right] \mathrm{L}$-serine or $\left[{ }^{3} \mathrm{H}\right]$ glycine (M. J. Schell and S. H. Snyder, unpublished observations). Thus, released $\mathrm{D}$-serine would be present in the synaptic space longer than glycine, with a greater opportunity to stimulate adjacent NMDA receptors, and any saturated "glycine sites" are more likely to be saturated with D-serine. 
In summary, the detailed comparisons of glycine, D-serine, and NR2A/B support our previous conclusions that D-serine is the endogenous ligand for the glycine site of telencephalic NMDA receptors. D-Serine also seems to be important in NMDARmediated development of the cerebellum. In the brainstem and spinal cord, where no D-serine is found and functional NMDA receptors are known to exist, endogenous glycine most likely modulates these sites. Why nature should use D-serine at certain synapses and glycine at others is a mystery. Differences in dynamics of the two transmitters, one in glia and the other in neurons, may be relevant.

\section{REFERENCES}

Altman J (1972) Postnatal development of the cerebellar cortex in the rat. II. Phases in the maturation of Purkinje cells and of the molecular layer. J Comp Neurol 145:399-463.

Campistron G, Buijs RM, Geffard M (1986) Glycine neurons in the brain and spinal cord: antibody production and immunocytochemical localization. Brain Res 376:400-405.

Chouinard ML, Gaitan D, Wood PL (1993) Presence of the $N$-methylD-aspartate-associated glycine receptor agonist, D-serine, in human temporal cortex: comparison of normal, Parkinson, and Alzheimer tissues. J Neurochem 61:1561-1564.

Corrigan JJ (1969) D-amino acids in animals. Science 164:142-149.

Cotman CW, Monaghan DT, Ottersen OP, Storm-Mathisen J (1987) Anatomical organization of excitatory amino acid receptors and their pathways. Trends Neurosci 10:273-280.

Crepel F, Dhanjal SS, Sears TA (1982) Effect of glutamate, aspartate and related derivatives on cerebellar Purkinje cell dendrites in the rat: an in vitro study. J Physiol (Lond) 329:297-317.

Cull-Candy S (1995) NMDA receptors: do glia hold the key? Curr Biol 5:841-843.

Daly EC, Nadi NS, Aprison MH (1976) Regional distribution and properties of the glycine cleavage system within the central nervous system of the rat: evidence for an endogenous inhibitor during in vitro assay. J Neurochem 26:179-185.

D'Angelo E, Rossi P, Taglietti V (1993) Different proportions of $N$-methyl-D-aspartate and non- $N$-methyl-D-aspartate receptor currents at the mossy fibre-granule cell synapse of developing rat cerebellum. Neuroscience 53:121-130.

Dupont JL, Gardette R, Crepel F (1987) Postnatal development of the chemosensitivity of rat cerebellar Purkinje cells to excitatory amino acids: an in vitro study. Brain Res 431:59-68.

Ennis M, Zimmer LA, Shipley MT (1996) Olfactory nerve stimulation activates rat mitral cells via NMDA receptors in vitro. NeuroReport 7:989-992.

Farrant M, Feldmeyer D, Takahashi T, Cull-Candy SG (1994) NMDAreceptor channel diversity in the developing cerebellum. Nature 368:335-339.

Fedele E, Smith D, Foster AC (1993) Autoradiographical evaluation of $\left[{ }^{3} \mathrm{H}\right]$ glycine uptake in rat forebrain: cellular localization in the hippocampus. Neurosci Lett 161:4-8.

Garthwaite G, Yamini Jr B, Garthwaite J (1987) Selective loss of Purkinje and granule cell responsiveness to $N$-methyl-D-aspartate in rat cerebellum during development. Brain Res 433:288-292.

Garthwaite J, Brodbelt AR (1989) Synaptic activation of $N$-methyl-Daspartate and non- $N$-methyl-D-aspartate receptors in the mossy fibre pathway in adult and immature rat cerebellar slices. Neuroscience 29:401-412.

Halpern M (1987) The organization and function of the vomeronasal system. Annu Rev Neurosci 10:325-362.

Hashimoto A, Nishikawa T, Hayashi T, Fujii N, Harada K, Oka T, Takahashi K (1992a) The presence of free D-serine in rat brain. FEBS Lett 296:33-36.

Hashimoto A, Nishikawa T, Oka T, Takahashi K, Hayashi T (1992b) Determination of free amino acid enantiomers in rat brain and serum by high-performance liquid chromatography after derivatization with $N$-tert.-butyloxycarbony-L-cysteine and $o$-phthaldialdehyde. J Chromatogr 582:41-48.

Hashimoto A, Kumashiro S, Nishikawa T, Oka T, Takahashi K, Mito T, Takashima S, Doi N, Mizutani Y, Yamazaki T (1993a) Embryonic development and postnatal changes in free $\mathrm{D}$-aspartate and $\mathrm{D}$-serine in the human prefrontal cortex. J Neurochem 61:348-351.
Hashimoto A, Nishikawa T, Oka T, Takahashi K (1993b) Endogenous D-serine in rat brain: $N$-methyl-D-aspartate receptor-related distribution and aging. J Neurochem 60:783-786.

Hashimoto A, Oka T, Nishikawa T (1995a) Anatomical distribution and postnatal changes in endogenous free $\mathrm{D}$-aspartate and $\mathrm{D}$-serine in rat brain and periphery. Eur J Neurosci 7:1657-1663.

Hashimoto A, Oka T, Nishikawa T (1995b) Extracellular concentration of endogenous free D-serine in the rat brain as revealed by in vivo microdialysis. Neuroscience 66:635-643.

Horiike K, Tojo H, Arai R, Yamano T, Nozaki M, Maeda T (1987) Localization of D-amino acid oxidase in Bergmann glial cells and astrocytes of rat cerebellum. Brain Res Bull 19:587-596.

Johnson JW, Ascher P (1987) Glycine potentiates the NMDA response in cultured mouse brain neurons. Nature 325:529-531.

Jursky F, Nelson N (1996) Developmental expression of the glycine transporters GLYT1 and GLYT2 in mouse brain. J Neurochem 67:336-344.

Kemp JA, Leeson PD (1993) The glycine site of the NMDA receptorfive years on. Trends Pharmacol Sci 14:20-25.

Komuro H, Rakic P (1993) Modulation of neuronal migration by NMDA receptors. Science 260:95-97.

Kosaka T, Nagatsu I, Wu JY, Hama K (1986) Use of high concentrations of glutaraldehyde for immunocytochemistry of transmitter-synthesizing enzymes in the central nervous system. Neuroscience 18:975-990.

Kutsuwada T, Kashiwabuchi N, Mori H, Sakimura K, Kushiya E, Araki K, Meguro H, Masaki H, Kumanishi T, Arakawa M (1992) Molecular diversity of the NMDA receptor channel. Nature 358:36-41.

Lahoya JL, Benavides J, Ugarte M (1980) Glycine metabolism and glycine synthase activity during the postnatal development of rat brain. Dev Neurosci 3:75-80.

Larson AA, Beitz AJ (1988) Glycine potentiates strychnine-induced convulsions: role of NMDA receptors. J Neurosci 8:3822-3826.

Liu CJ, Grandes P, Matute C, Cuenod M, Streit P (1989) Glutamate-like immunoreactivity revealed in rat olfactory bulb, hippocampus and cerebellum by monoclonal antibody and sensitive staining method. Histochemistry 90:427-445.

Llano I, Marty A, Armstrong CM, Konnerth A (1991) Synaptic- and agonist-induced excitatory currents of Purkinje cells in rat cerebellar slices. J Physiol (Lond) 434:183-213.

Lynch DR, Anegawa NJ, Verdoorn T, Pritchett DB (1994) N-methyl-Daspartate receptors: different subunit requirements for binding of glutamate antagonists, glycine antagonists, and channel-blocking agents. Mol Pharmacol 45:540-545.

Matsui T, Sekiguchi M, Hashimoto A, Tomita U, Nishikawa T, Wada K (1995) Functional comparison of D-serine and glycine in rodents: the effect on cloned NMDA receptors and the extracellular concentration. J Neurochem 65:454-458.

Matute C, Gutierrez-Igarza K, Rio C, Miledi R (1994) Glutamate receptors in astrocytic end-feet. NeuroReport 5:1205-1208.

Meguro H, Mori H, Araki K, Kushiya E, Kutsuwada T, Yamazaki M, Kumanishi T, Arakawa M, Sakimura K, Mishina M (1992) Functional characterization of a heteromeric NMDA receptor channel expressed from cloned cDNAs. Nature 357:70-74.

Monyer H, Sprengel R, Schoepfer R, Herb A, Higuchi M, Lomeli H, Burnashev N, Sakmann B, Seeburg PH (1992) Heteromeric NMDA receptors: molecular and functional distinction of subtypes. Science 256:1217-1221.

Monyer H, Burnashev N, Laurie DJ, Sakmann B, Seeburg PH (1994) Developmental and regional expression in the rat brain and functional properties of four NMDA receptors. Neuron 12:529-540.

Moriyoshi K, Masu M, Ishii T, Shigemoto R, Mizuno N, Nakanishi S (1991) Molecular cloning and characterization of the rat NMDA receptor. Nature 354:31-37.

Nagata Y (1992) Involvement of D-amino acid oxidase in elimination of D-serine in mouse brain. Experientia 48:753-755.

Nagata Y, Horiike K, Maeda T (1994) Distribution of free D-serine in vertebrate brains. Brain Res 634:291-295.

Ottersen OP, Storm-Mathisen J, Somogyi P (1988) Colocalization of glycine-like and GABA-like immunoreactivities in Golgi cell terminals in the rat cerebellum: a postembedding light and electron microscopic study. Brain Res 450:342-353.

Palay SL, Chan-Palay V (1974) Cerebellar cortex: cytology and organization. New York: Springer.

Petralia RS, Wang YX, Wenthold RJ (1994a) The NMDA receptor 
subunits NR2A and NR2B show histological and ultrastructural localization patterns similar to those of NR1. J Neurosci 14:6102-6120.

Petralia RS, Yokotani N, Wenthold RJ (1994b) Light and electron microscope distribution of the NMDA receptor subunit NMDAR1 in the rat nervous system using a selective anti-peptide antibody. J Neurosci 14:667-696.

Portera-Cailliau C, Price DL, Martin LJ (1996) N-methyl-D-aspartate receptor proteins NR2A and NR2B are differentially distributed in the developing rat central nervous system as revealed by subunit-specific antibodies. J Neurochem 66:692-700.

Pourcho RG, Goebel DJ, Jojich L, Hazlett JC (1992) Immunocytochemical evidence for the involvement of glycine in sensory centers of the rat brain. Neuroscience 46:643-656.

Priestley T, Laughton P, Myers J, Le Bourdelles B, Kerby J, Whiting PJ (1995) Pharmacological properties of recombinant human $N$-methyl-Daspartate receptors comprising NR1a/NR2A and NR1a/NR2B subunit assemblies expressed in permanently transfected mouse fibroblast cells. Mol Pharmacol 48:841-848.

Quinlan JE, Davies J (1985) Excitatory and inhibitory responses of Purkinje cells, in the rat cerebellum in vivo, induced by excitatory amino acids. Neurosci Lett 60:39-46.

Rabacchi S, Bailly Y, Delhaye-Bouchaud N, Mariani J (1992) Involvement of the $N$-methyl D-aspartate (NMDA) receptor in synapse elimination during cerebellar development. Science 256:1823-1825.

Raisman G (1985) Specialized neuroglial arrangement may explain the capacity of vomeronasal axons to reinnervate central neurons. Neuroscience 14:237-254.

Ramon-Cueto A, Valverde F (1995) Olfactory bulb ensheathing glia: a unique cell type with axonal growth-promoting properties. Glia 14:163-173.

Reynolds IJ, Murphy SN, Miller RJ (1987) 3H-labeled MK-801 binding to the excitatory amino acid receptor complex from rat brain is enhanced by glycine. Proc Natl Acad Sci USA 84:7744-7748.

Richter K, Hamprecht B, Scheich H (1996) Ultrastructural localization of glycogen phosphorylase predominantly in astrocytes of the gerbil brain. Glia 17:263-273.

Rossi DJ, Slater NT (1993) The developmental onset of NMDA receptor-channel activity during neuronal migration. Neuropharmacology 32:1239-1248.

Salt TE (1989) Modulation of NMDA receptor-mediated responses by glycine and D-serine in the rat thalamus in vivo. Brain Res 481:403-406.

Sato K, Yoshida S, Fujiwara K, Tada K, Tohyama M (1991) Glycine cleavage system in astrocytes. Brain Res 567:64-70.

Schell MJ, Molliver ME, Snyder SH (1995) D-serine, an endogenous synaptic modulator: localization to astrocytes and glutamate-stimulated release. Proc Natl Acad Sci USA 92:3948-3952.

Schmitt ML, Coelho W, Lopes-de-Souza AS, Guimaraes FS, Carobrez AP
(1995) Anxiogenic-like effect of glycine and D-serine microinjected into dorsal periaqueductal gray matter of rats. Neurosci Lett 189:93-96.

Singh L, Oles RJ, Tricklebank MD (1990) Modulation of seizure susceptibility in the mouse by the strychnine-insensitive glycine recognition site of the NMDA receptor/ion channel complex. $\mathrm{Br} \mathrm{J}$ Pharmacol 99:285-288.

Southam E, East SJ, Garthwaite J (1991) Excitatory amino acid receptors coupled to the nitric oxide/cyclic GMP pathway in rat cerebellum during development. J Neurochem 56:2072-2081.

Steindler DA (1993) Glial boundaries in the developing nervous system. Annu Rev Neurosci 16:445-470.

Thiels E, Weisz DJ, Berger TW (1992) In vivo modulation of $N$-methyl$\mathrm{D}$-aspartate receptor-dependent long-term potentiation by the glycine modulatory site. Neuroscience 46:501-509.

Trombley PQ, Shepherd GM (1994) Glycine exerts potent inhibitory actions on mammalian olfactory bulb neurons. J Neurophysiol 71:761-767.

Tsacopoulos M, Magistretti J (1996) Metabolic coupling between glia and neurons. J Neuroscience 16:877-885.

van den Pol AN, Gorcs T (1988) Glycine and glycine receptor immunoreactivity in brain and spinal cord. J Neurosci 8:472-492.

Watanabe M, Inoue Y, Sakimura K, Mishina M (1992) Developmental changes in distribution of NMDA receptor channel subunit mRNAs. NeuroReport 3:1138-1140.

Watanabe M, Mishina M, Inoue Y (1994) Distinct spatiotemporal expressions of five NMDA receptor channel subunit mRNAs in the cerebellum. J Comp Neurol 343:513-519.

Weimar WR, Neims AH (1977a) The development of D-amino acid oxidase in rat cerebellum. J Neurochem 29:649-656.

Weimer WR, Neims AH (1977b) Hog cerebellar D-amino acid oxidase and its histochemical and immunofluorescent localization. J Neurochem 28:559-572.

Wilkin GP, Csillag A, Balazs R, Kingsbury AE, Wilson JE, Johnson AL (1981) Localization of high affinity $\left[{ }^{3} \mathrm{H}\right]$ glycine transport sites in the cerebellar cortex. Brain Res 216:11-33.

Wood PL, Emmett MR, Rao TS, Mick S, Cler J, Iyengar S (1989) In vivo modulation of the $N$-methyl-D-aspartate receptor complex by D-serine: potentiation of ongoing neuronal activity as evidenced by increased cerebellar cyclic GMP. J Neurochem 53:979-981.

Zafra F, Aragon C, Olivares L, Danbolt NC, Gimenez C, Storm-Mathisen J (1995) Glycine transporters are differentially expressed among CNS cells. J Neurosci 15:3952-3969.

Zalutsky RA, Nicoll RA (1990) Comparison of two forms of long-term potentiation in single hippocampal neurons. Science 248:1619-1624.

Zheng JQ, Wan JJ, Poo M-M (1996) Essential role of filopodia in chemotropic turning of nerve growth cone induced by a glutamate gradient. J Neurosci 16:1140-1149. 